2. To: (Receiving Organization)

Distribution

5. Proj./Prog./Dept./Div.:

WHC TWRS Disposal

Engineering

8. Originator Remarks:

The attached Design Requirements Document is issued for approval and release.
3. From: (Originating Organization)

WHC TWRS Disposal Engineering

R. J. Parazin

6. Cognizant Engr.:

R. J. Parazin
4. Releted EDT Ho.: 606379

7. Purchase Order No.:

$N / A$

11. Receiver Remarks: 11A. Design Basel ine Document? [ ] Yes [X] No

9. Equip./Component No.: N/A

10. System/Bldg./Facility: N/A

12. Mejor Assm. Dwg. Mo.:

13. Permit/Permit Application No.:

14. Required Response Date: Sept 30,1996

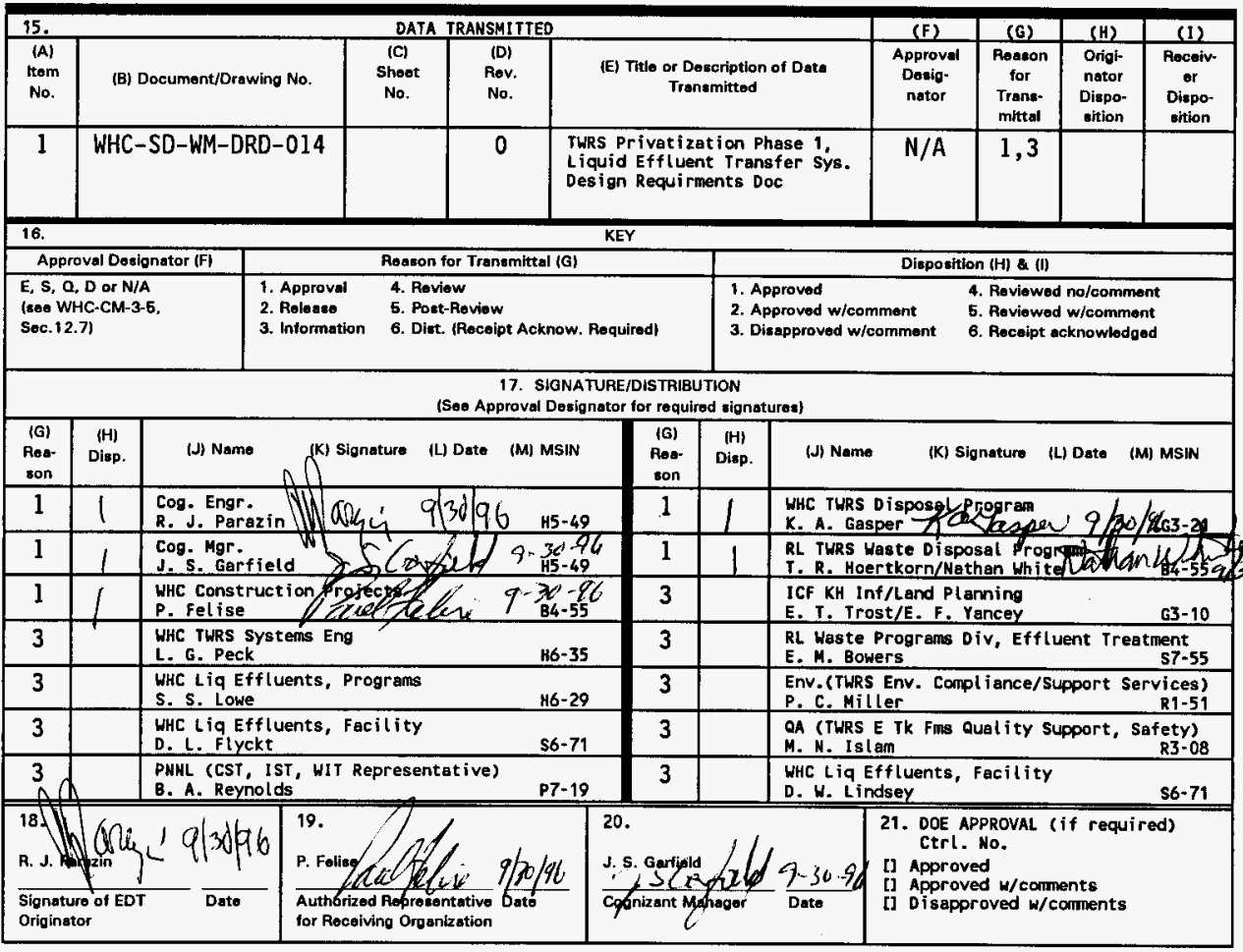




\title{
DESIGN REQUIREMENTS DOCUMENT
}

\author{
PRIVATIZATION PHASE I
}

LIQUID EFFLUENT TRANSFER SYSTEMS

prepared by ICF Kaiser Hanford Company

for Westinghouse Hanford Company

\section{SEPTEMBER 1996}

Prepared by: $\frac{A \cdot N \cdot P \text { Pali }}{\text { A.N. Palit, ICF KH/TFRSO Piping Engineer }}$

$\frac{9 / 30 / 96}{\text { Date }}$

Concurrence:

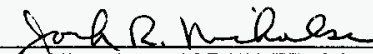

J.K. Nicholson, ICF KH/TFRSO Piping Lead Engineer

$9 / 30 / 96$

concurrence: $\frac{\text { T. D. Whendal }}{\text { M.D. Rickenbach, ICF KH/TFRSO Principal Lead Engineer }}$

$\frac{7 / 30 / 96}{\text { Date }}$

concurrence: $\frac{\text { M. O Rehutace To I. T. totas }}{\text { J.T. Koberg, ICF KH/TFRSO Project Manager }}$

$\frac{9 / 30 / 96}{\text { Date }}$ 


\title{
TWRS PRIVATIZATION PHASE 1 LIQUID EFFLUENT TRANSFER SYSTEMS DESIGN REQUIREMENTS DOCUMENT
}

\author{
R. J. Parazin
}

Westinghouse Hanford Company, Richland, WA 99352

U.S. Department of Energy Contract DE-AC06-87RL10930

\author{
EDT/ECN: $618855 \quad$ UC: 721 \\ Org Code: 73520 Charge Code: D627F \\ B\&R Code: EW3130000 Total Pages: 38
}

Key Words: TWRS Privatization, Phase 1, liquid effluent transfer, privatization, privatization contractor, effluent treatment, liquid effluent design requirements, DRD

Abstract: The DOE-RL is pursuing a new business strategy of hiring private contractors for treatment of Hanford tank waste. This

'privatization' initiative includes design, permitting, construction, operations, deactivation and decommissioning of tank waste treatment facilities. The TWRS Privatization Infrastructure Project is part of the first phase of the initiative and includes several sub-projects to provide key physical interfaces and services needed to support the mission. One sub-project is to provide transfer systems integrated with 200 Area liquid effluent facilities to service the private contractors. This document presents the applicable liquid effluent transfer systems' design requirements to be used as a basis for conceptual design.

TRADEMARK DISCLAIMER. Reference herein to any specific comercial product, process, or service by trade name, trademark, manufacturer, or otherwise, does not necessarily constitute or imply its endorsement, recommendation, or favoring by the United states Government or any agency thereof or its contractors or subcontractors.

Printed in the United States of America. To obtain copies of this document, contact: WHC/BCS Document Control Services, P.O. Box 1970, Mailstop H6-OB, Richland WA 99352, Phone (509) 372-2420; Fax (509) 376-4989.

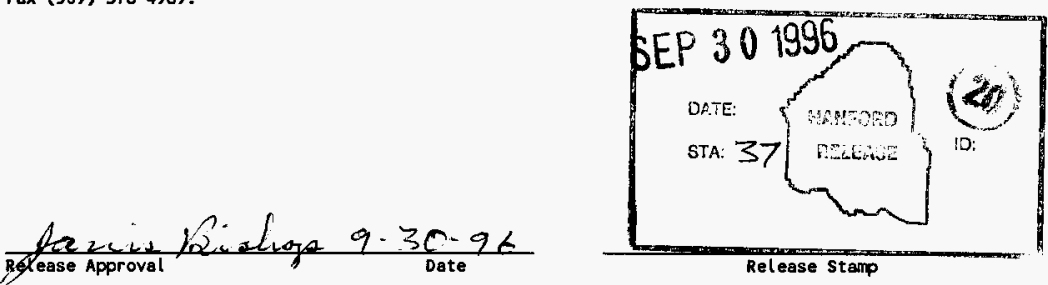




\title{
DESIGN REQUIREMENTS DOCUMENT
}

\author{
FOR \\ PRIVATIZATION PHASE I \\ LIQUID EFFLUENT TRANSFER SYSTEMS
}

SEPTEMBER 1996

Prepared for

U. S. Department of Energy Richland Field Office Richland, Washington

by

Westinghouse Hanford Company

Richland, Washington 99352 


\section{TABLE OF CONTENTS}

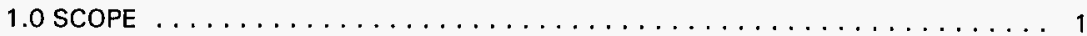

1.1 IDENTIFICATION $\ldots \ldots \ldots \ldots \ldots \ldots \ldots \ldots \ldots \ldots \ldots \ldots$

1.2 SYSTEM OVERVIEW $\ldots \ldots \ldots \ldots \ldots \ldots \ldots \ldots \ldots \ldots \ldots \ldots \ldots$

1.3 DOCUMENT OVERVIEW $\ldots \ldots \ldots \ldots \ldots \ldots \ldots \ldots \ldots \ldots \ldots$

2.0 APPLICABLE DOCUMENTS $\ldots \ldots \ldots \ldots \ldots \ldots \ldots \ldots \ldots \ldots$

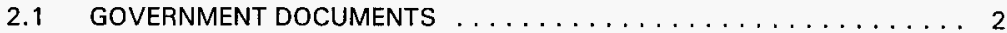

2.2 NON-GOVERNMENT DOCUMENTS $\ldots \ldots \ldots \ldots \ldots \ldots \ldots \ldots$

3.0 SYSTEM FUNCTIONS AND REQUIREMENTS $\ldots \ldots \ldots \ldots \ldots \ldots \ldots$

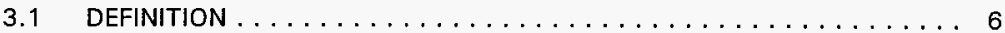

3.2 CHARACTERISTICS $\ldots \ldots \ldots \ldots \ldots \ldots \ldots \ldots \ldots \ldots \ldots \ldots \ldots$

3.2.1 PERFORMANCE CHARACTERISTICS ............. 9

3.2 .2 SYSTEM RELATIONSHIPS . . . . . . . . . . . . 10

3.2 .3 EXTERNAL INTERFACE REQUIREMENTS $\ldots \ldots \ldots \ldots \ldots \ldots$

3.2 .4 PHYSICAL CHARACTERISTICS . . . . . . . . . . . . . 14

3.2 .5 SYSTEM QUALITY FACTORS . . . . . . . . . . . . . . . . . . 14

3.2.6 ENVIRONMENTAL CONDITIONS $\ldots \ldots \ldots \ldots \ldots \ldots \ldots \ldots$

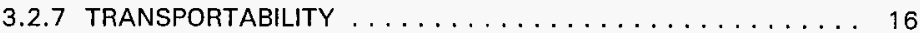

3.2 .8 FLEXIBILITY AND EXPANSION $\ldots \ldots \ldots \ldots \ldots \ldots \ldots \ldots$

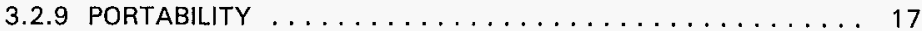

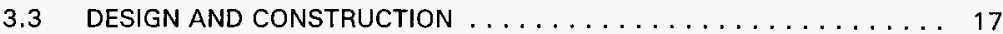

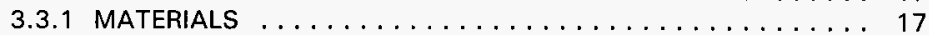

3.3 .2 ELECTROMAGNETIC RADIATION $\ldots \ldots \ldots \ldots \ldots \ldots \ldots \ldots \ldots . \ldots \ldots$

3.3 .3 NAMEPLATES AND PRODUCT MARKINGS . . . . . . . . . . 18

3.3 .4 WORKMANSHIP $\ldots \ldots \ldots \ldots \ldots \ldots \ldots \ldots \ldots \ldots$

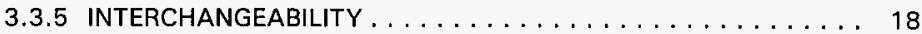

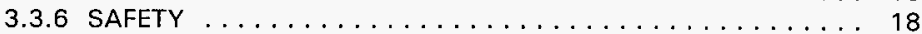

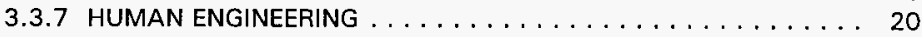

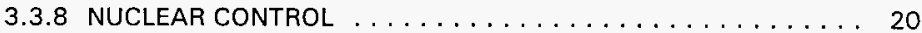

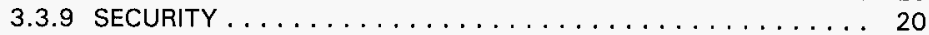

3.3.10 GOVERNMENT FURNISHED PROPERTY USAGE . . . . . . . . 21

3.3.11 COMPUTER RESOURCE RESERVE CAPACITY . . . . . . . . 21

3.3.12 PIPING AND ANCILLARY EQUIPMENT DESIGN AND

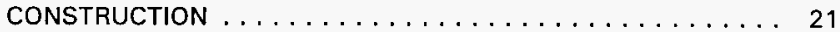

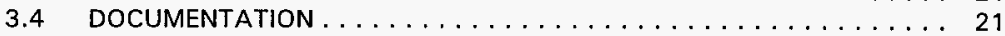

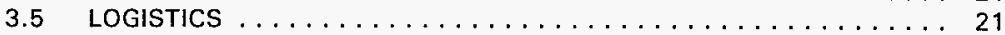

3.5.1 MAINTENANCE AND OPERATION ... . . . . . . . . . 21

3.5 .2 WASTE HANDLING, STORAGE, AND DISPOSAL . . . . . . . . 22

3.5.3 TRANSPORTATION OF HAZARDOUS MATERIALS . . . . . . 22

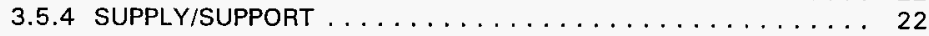




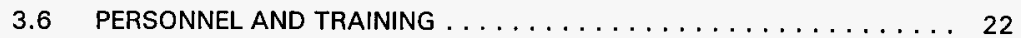

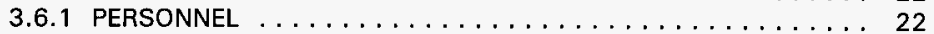

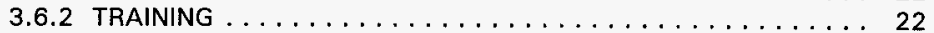

3.7 CHARACTERISTICS OF SUBORDINATE ELEMENTS $\ldots \ldots \ldots \ldots \ldots \ldots$

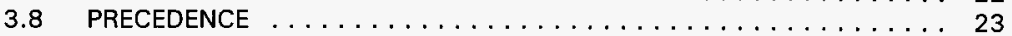

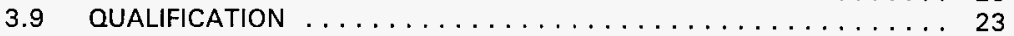

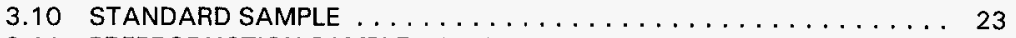

3.11 PREPRODUCTION SAMPLE, PERIODIC PRODUCTION SAMPLE, PILOT

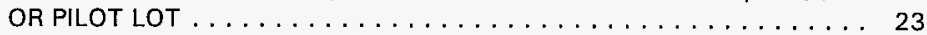

4.0 QUALITY ASSURANCE PROVISIONS $\ldots \ldots \ldots \ldots \ldots \ldots \ldots \ldots \ldots \ldots$

4.1 RESPONSIBILITY FOR INSPECTION $\ldots \ldots \ldots \ldots \ldots \ldots \ldots \ldots \ldots$

4.2 SPECIAL TESTS AND EXAMINATIONS $\ldots \ldots \ldots \ldots \ldots \ldots \ldots \ldots$

4.3 REQUIREMENTS CROSS REFERENCE $\ldots \ldots \ldots \ldots \ldots \ldots \ldots$

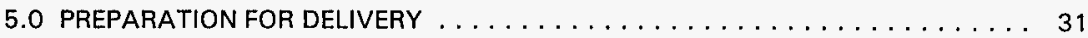

6.0 NOTES . . . . . . . . . . . . . . . . . . . . . . . 31

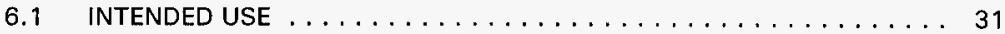

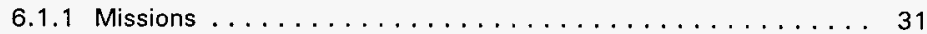

6.1 .2 Hazards . . . . . . . . . . . . . . . . . . 31

6.2 DEFINITIONS . . . . . . . . . . . . . . . . . . . 31

6.2 .1 RADIOACTIVE, DANGEROUS LIQUID EFFLUENT . . . . . . . . . . . 31

6.2.2 NON-RADIOACTIVE, NON-DANGEROUS LIQUID EFFLUENT . . . 31

6.3 ABBREVIATIONS AND ACRONYMS $\ldots \ldots \ldots \ldots \ldots \ldots \ldots \ldots$

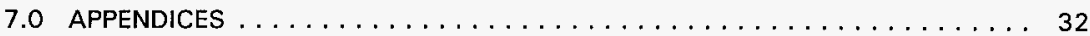


TABLES

Table 4.3-1 Requirements Cross Reference . . . . . . . . . . . . . . . 25

\section{FIGURES}

Figure 3.1-1 Non-Radioactive, Non-Dangerous Liquid Effluent System Architecture . . 7

Figure 3.1-2 Radioactive,Dangerous Liquid Effluent System Architecture . . . . . . . . 8

Figure 3.2-1 Non-Radioactive, Non-Dangerous Liquid Effluent Transfer System . . . . 12

Figure 3.2-2 Radioactive,Dangerous Liquid Effluent Transfer System . . . . . . . . 13 


\subsection{SCOPE}

\subsection{IDENTIFICATION}

$\begin{array}{ll}\text { Program: } & \text { Tank Waste Remediation System (TWRS) } \\ \text { Project: } & \text { TWRS Privatization Infrastructure Project (IP) } \\ \text { Systems: } & \begin{array}{l}\text { Non-Radioactive, Non-Dangerous Liquid Effluent } \\ \text { Radioactive, Dangerous Liquid Effluent }\end{array}\end{array}$

\subsection{SYSTEM OVERVIEW}

The U.S. Department of Energy (DOE), Richland Operations Office, is pursuing a new business strategy of hiring private contractors (PC) for treatment of Hanford Site tank wastes. This strategy, called privatization, includes design, permitting, construction, operation, and deactivation of equipment and facilities for treatment of tank wastes. The Phase I of the privatization includes supernatant pretreatment, low level waste (LLW) immobilization, and an optional high-level waste (HLW) immobilization. The TWRS Privatization Infrastructure Project (IP) is a part of the first phase of the privatization initiative. The IP consists of several sub-projects which will provide key physical interfaces and services needed to support the privatization mission. The liquid effluent transfer is one of the sub-projects.

During Phase I the Double Shell Tank (DST) supernate would be provided to two private contractors for pretreatment and immobilization into a low-activity waste (LAW) product from June 2002 through June 2007. The PC facilities may run through 2011 if extended by DOE. The DOE or its agent, the Project Hanford Management Contractor (PHMC) is responsible for accepting liquid effluent from boundary of the PC facilities for disposal at the 200 Area liquid effluent disposal facilities.

\subsection{DOCUMENT OVERVIEW}

This document sets forth functional requirements, performance requirements, interface requirements, and design constraints for the liquid effluent transfer systems identified in Section 3.1. These requirements and constraints will be used to develop the Design Requirements Baseline for the liquid effluent transfer systems.

\subsection{APPLICABLE DOCUMENTS}

The following documents of the exact issue shown form a part of the requirements of this Design Requirements Documents (DRD) to the extent specified herein. In the 
event of a conflict between the documents referenced herein and the contents of this DRD, due to subsequent compliance document interpretations or revisions, the requirements of this $\mathrm{DRD}$ shall be considered a superseding requirement until required DRD changes are instituted through the formal change control process.

\subsection{GOVERNMENT DOCUMENTS}

\section{SPECIFICATIONS:}

10 CFR 835

29 CFR 1910

40 CFR 61

40 CFR 262

40 CFR 268

6OFR31115

DOE/RL, 5400.xy

DOE/RL, 5400.1

DOE/RL-90-43

DOE 1540.1

DOE 5400.5

DOE 5480.4

DOE 5480.7A

DOE 5480.19

DOE 5480.20A

DOE 5480.23
Department of Energy Occupational Radiation Protection

Occupational Safety and Health Standards

National Emission Standards for Hazardous Air Pollutants 1994

Hazardous Waste Management

Land Disposal Restrictions

EPA Approval of Delisting Petition, DOE/RL-92-72

Radiation Effluent Monitoring and Environmental Surveillance

General Environmental Protection Program

LERF Part B Permit Application

Materials Transportation and Traffic Management

Radiation Protection of the Public and the Environment (1990a)

Environmental Protection, Safety and Health Protection (1993)

Fire Protection (1993)

Conduct of Operations Requirements for DOE Facilities (DOE 1990)

Personnel Selection, Qualification, Training, and Staffing Requirements at DOE Reactor and Non-Reactor Facilities

Nuclear Safety Analysis Reports 
DOE 5700.6C Quality Assurance (DOE 1991)

DOE 5820.2A Radioactive Waste Management

DOE 6430.1A United States Department of Energy, General Design Criteria (DOE 1989)

DE-RP06-96RL13308 TWRS Privatization Request for Proposals (RFP)

\section{STANDARDS:}

MIL-STD-1472D Human Engineering Design Criteria for Military Systems Equipment and Facilities

\section{DRAWINGS:}

N/A

OTHER PUBLICATIONS:

GC-LOAD-01 Standard Arch-Civil Design Criteria, Design Loads for Facilities (RL 1993)

GG-DWG-01

A/E General Standard

HSRCM-1

Hanford Site Radiological Control Manual

NUREG 0700

Guidelines for Control Design Reviews

NUREG CR-2496

Human Engineering Design Considerations for Cathode Ray Generated Displays

UCRL 15673 Human Factors Design Guidelines for Maintainability of DOE Nuclear Facilities

WHC-CM-2-14 Hazardous Material Packaging and Shipping

WHC-CM-3-5 Document Control and Records Management Manual

WHC-CM-4-3 Industrial Safety Manual

WHC-CM-4-40 Industrial Hygiene Manual 
WHC-CM-4-46 Non-Reactor Facility Safety Analysis Manual

WHC-CM-6-3 Drafting Standards Manual

WHC-CM-7-5 Environmental Compliance

WHC-EP-0063-4 Hanford Site Solid Waste Acceptance Criteria

WHC-IP-1140 Workmanship Standards

WHC-IP-1043 WHC Occupational ALARA Program

WHC-SD-GN-DGS-30008 Design loads for New Underground DSTs and Associated Underground Process Piping

WHC-SD-GN-DGS-30011 Radiological Design Guide

WHC-SD-WM-DRD-013 Design Requirements Document for Privatization Phase I, Roads \& Rail System Modifications \& Site Development

WHC-SD-W049H-ICD-001 200 Area Treated effluent disposal Facility Interface Control Document

WHC-SD-ETF-WAC-001 Acceptance of Feed Streams for Treatment at the LERF/ETF complex

WHC-SD-W105-SAR-001 Liquid Effluent Retention Facility FSAR

WHC-SD-TWR-ES-002 Engineering Study, TWRS Privatization Phase I, Raw and potable water Service (Draft)

WHC-SD-WM-ES-396

Engineering Study, Privatization Phase !, Liquid Effluent Transfer Systems (Draft)

WHC-SD-WM-FRD-020

TWRS Functions and Requirements Document

WAC-173-200

Water Quality Standards for Ground Waters of State of Washington

WAC 173-216

State Waste Discharge Permit Program

WAC 173-303

Dangerous Waste Regulations

Permit No. ST4500

State Waste Discharge Permit 
Permit No. ST4502 State Waste Discharge Permit

\subsection{NON-GOVERNMENT DOCUMENTS}

DRAWINGS:

$\mathrm{H}-2-140342$, Rev. 2 Civil Line H STA $0+00$ to STA $32+23$

H-2-79604, Rev. 2 Piping Plot and Key Plans 242-A Evap Cond Stream

\section{SPECIFICATIONS:}

N/A

STANDARDS:

ANSI/ANS-3.2-88 Administrative Controls and Quality Assurance for the Operational Phase of Nuclear Power Plants

ASME-NQA-1-1989-1A Quality Assurance Program Requirements for Nuclear Facilities (1986)

NFPA 70 National Fire Protection Association, National Electric Code (1993) 


\subsection{SYSTEM FUNCTIONS AND REQUIREMENTS}

\subsection{DEFINITION}

The primary function of the liquid effluent transfer system is to support transfer of the effluents from the PCs' site boundaries to the 200 Area liquid effluent disposal facilities as follows:

- Liquid effluents which meet interface acceptance criteria for discharge directly to the 200 Area Treated Effluent Disposal Facility (TEDF). Figure 3.11 depicts the architecture required to accomplish the effluent transfer.

- Liquid effluents which require treatment and meet interface acceptance criteria for discharge directly to the Liquid Effluent Retention Facility (LERF) and subsequent treatment in the Effluent Treatment Facility (ETF). Figure 3.1-2 depicts the architecture required to accomplish the effluent transfer.

The major sub-elements that makeup a liquid effluent transfer system are briefly described below:

a. Piping system. The effluent transfer piping system consisting of primary pipe for non-radioactive, non-dangerous effluents or double-contained pipe for radioactive, dangerous effluents used to route the effluent liquid, flanges, couplings and other ancillary equipment (e.g., fittings, valves).

b. Transfer pumps. The effluent transfer mechanism required to provide motive force to move liquid effluent from source location in the PC facility to the destination at the disposal site.

c. Instrumentation and control system. The effluent transfer instrumentation and control system consisting of the controls, monitoring devices, instrumentation devices and cabling required to properly supervise and operate the effluent transfer.

d. Power system. The effluent transfer power system consists of transformers, load centers, motor control centers, distribution boxes, power cabling, and associated ancillary equipment for items requiring electrical power. 


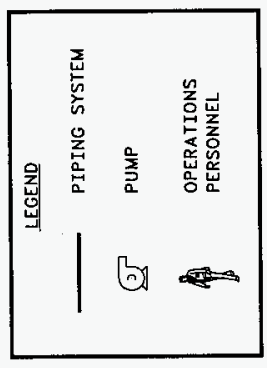

至
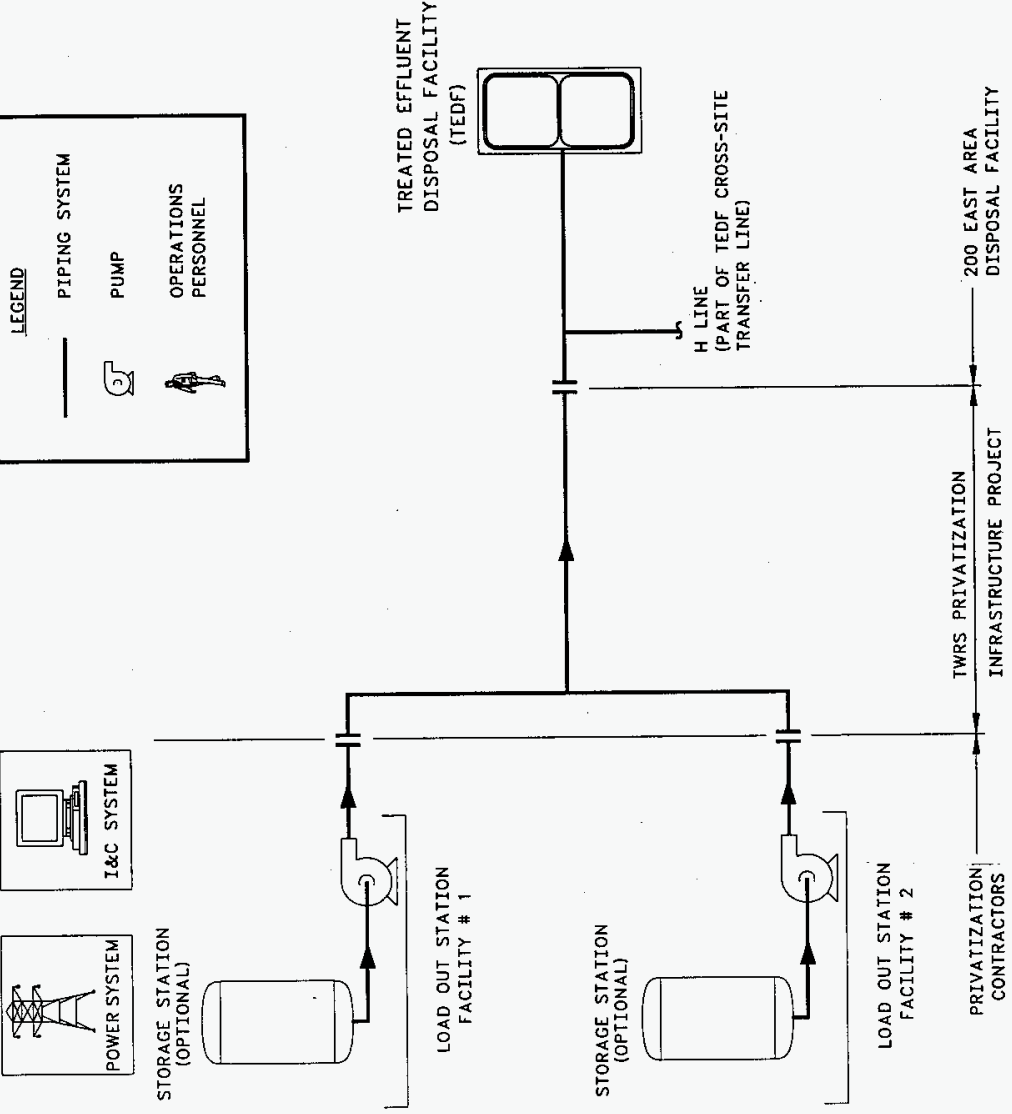

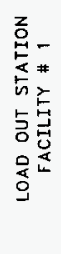

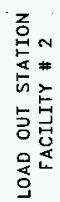

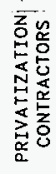

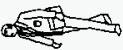

Figure 3.1-1 Non-Radioactive, Non-Dangerous Liquid Effluent System Architecture 


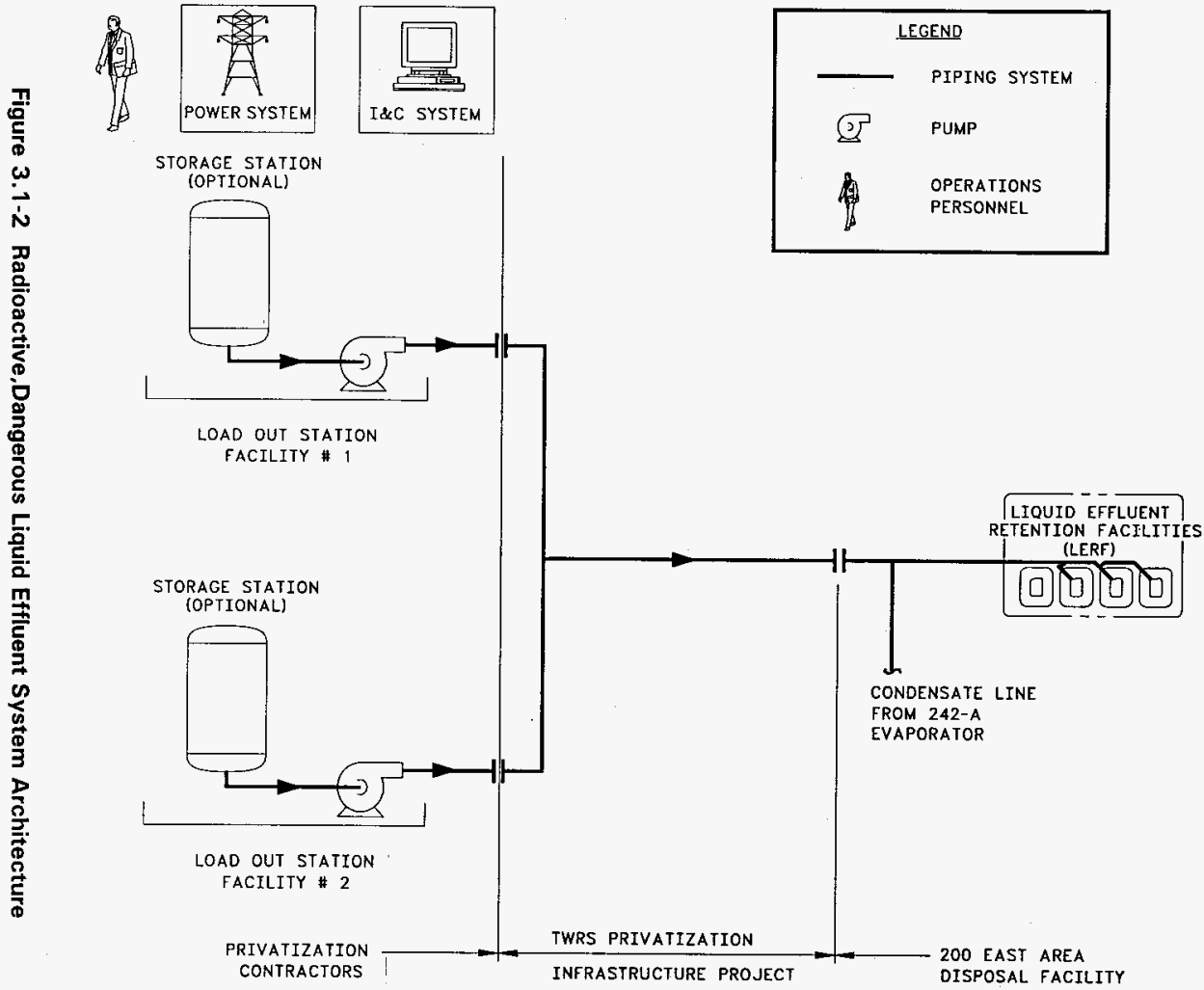


WHC-SD-WM-DRD-014

Revision 0

\subsection{CHARACTERISTICS}

\subsubsection{PERFORMANCE CHARACTERISTICS}

The system components shall meet the following performance characteristics specified within this document.

3.2.1.1 Non-Radioactive, Non-Dangerous Effluent Discharge Flow Rate. The nonradioactive, non-dangerous effluent discharge flow rate from two contractors combined shall be 133,000 cubic meters/year ( $35 \mathrm{Mgal} /$ year) maximum. The rate is a bounding figure acknowledged both by the bidding PCs and DOE-RL during phase $1 \mathrm{~A}$ negotiations. The postulated volume is subject to further negotiation before the definitive design stage (RFP volume 300,000 cubic meters/yearl.

3.2.1.2 Radioactive, Dangerous Effluent Discharge Flow Rate. The radioactive, dangerous effluent discharge flow rate from two contractors combined shall be 100,000 cubic meters/year $(26 \mathrm{Mgal} /$ year) maximum (RFP volume 100,000 cubic meters/year).

3.2.1.3 Minimum Liquid Velocity. The piping system, for both types of effluents mentioned under section 3.1, shall be provided for collection and disposal of effluent liquid from the PC facilities and installed with a slope for gravity draining. The minimum liquid velocity of 61 centimeters ( 2 feet) per second at the average rate of flow shall be maintained.

3.2.1.4 Motive Force. The PC, for each type of effluent mentioned under section 3.1, shall connect its facility to the tie-in provided for the effluent transfer at the PC's site perimeter. The effluent transfer mechanism at the PC facility shall provide motive force to move liquid effluent from the source to the destination.

3.2.1.5 Monitoring Effluent Stream Parameters. The contractor generating facility will monitor each type of effluent mentioned under section 3.1 for flow and applicable process upset on a real-time and historical basis and indicating parameters such as $\mathrm{pH}$, conductivity, total alpha, and total beta. Monitoring system will initiate automated corrective actions, as appropriate, to protect the integrity of both the disposal facility and discharged effluent.

3.2.1.6 Radioactive, Dangerous Effluent Waste Acceptability Criteria. The waste acceptability criteria for storage and treatment at LERF/ETF have not been determined at this time. Only the waste codes listed under F001 through FO05 in the Delisting Petition can be accepted currently for treatment at the ETF. However the following operability parameters can be assumed as the starting point for the definitive design stage: 
a. Single phase aqueous waste streams containing no separable organics.

b. Minimize colloidal matter to protect filters in the ETF from plugging.

c. Minimize scale forming compounds concentrations within limitations of the Ultra Violet/oxidation and Reverse Osmosis units.

d. Minimize concentrations of corrosive constituent, such as chloride and fluoride.

e. Minimize concentration of constituents that can absorb ultra-violet light to the extent destruction of targeted organics is significantly compromised.

f. Waste streams containing no solids which may settle in the LERF basins.

g. The concentration of ammonia limited to $1 \mathrm{wt} \%(10,000 \mathrm{mg} / \mathrm{L}$ or $58 \mathrm{M})$.

3.2.1.7 Non-Radioactive, Non-Dangerous Effluent Acceptance Criteria. The effluent must meet the 200 Area TEDF Waste Acceptance Criteria (WHC-SD-WO49HICD-001I.

\subsubsection{SYSTEM RELATIONSHIPS}

Relationships between the functions performed by the effluent transfer systems and other, interfacing system functions cannot be identified at this time.

\subsubsection{EXTERNAL INTERFACE REQUIREMENTS}

3.2.3.1 Physical Descriptions. The physical interfaces described herein are based on the recommended routing of the underground effluent transfer piping (WHCSD-WM-ES-396) and these interfaces are depicted in Figure 3.2-1 and -2 . Additional scope and modification of the contents of this section may be required based on the results of the Baseline Comparison.

Buried pipelines will be used to transfer liquid effluents from PC facilities to the disposal sites. The effluent tie-in points for both the PC facilities will be located east of the grout vaults approximately between the coordinates N.39550/N.41400 and W.44950/W.43600. Each PC will discharge two fluid streams: Non-Radioactive Non-Dangerous Liquid Effluent and Radioactive, Dangerous Liquid Effluent. The privatization contractors shall not commingle different waste types.

3.2.3.2 Non-Radioactive Non-Dangerous Liquid Effluent. The proposed common route begins at coordinates W43650 and N41430 east of the PC facilities and runs straight west upto $\mathrm{W} 45000$. The route then turns north along the proposed interior road east of the PC facilities up to the proposed north asphalt concrete pavement (ACP) road for the privatization phase I stage (WHC-SDTWR-ES-002, Alternative 6). The route continues west along the north ACP road and tie-in with the corresponding existing disposal line suitable for the type of the effluent. The effluent pipeline will tie-in to the $\mathrm{H}$ LINE (Drawing $\mathrm{H}-2-140342)$ at $\mathrm{N} 41050$. The routing configuration is shown in Figure 3.2-1. 
3.2.3.3 Radioactive, Dangerous Liquid Effluent. The radioactive, dangerous liquid effluent pipeline will run parallel to non-radioactive non-dangerous liquid effluent and tie-in to the existing 242-A Evaporator condensate discharge line $\mathrm{PC5000}$ (Drawing $\mathrm{H}-2-79604$ ) at $\mathrm{N} 41050$. The routing configuration is shown in Figure 3.2-2. 


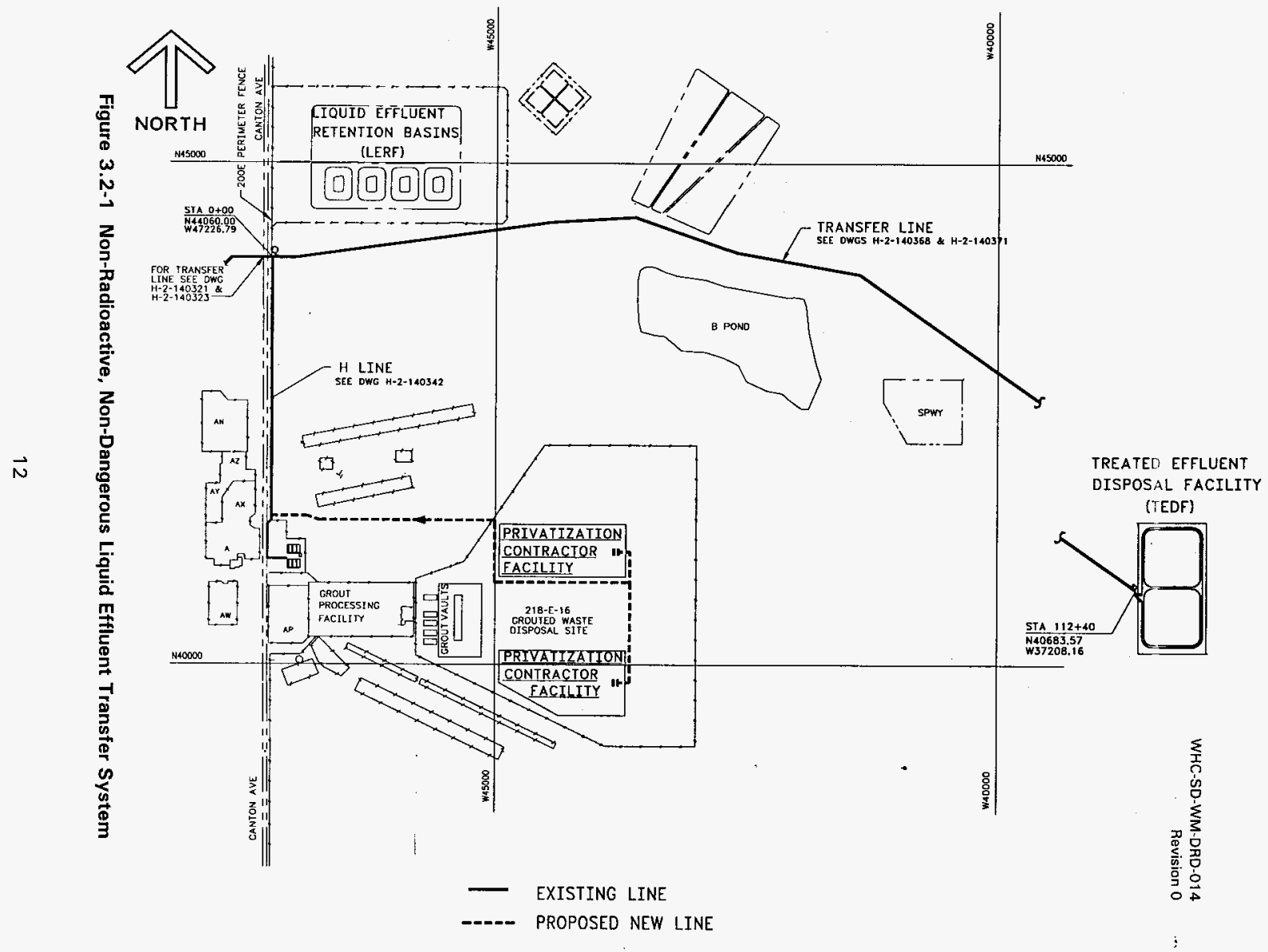




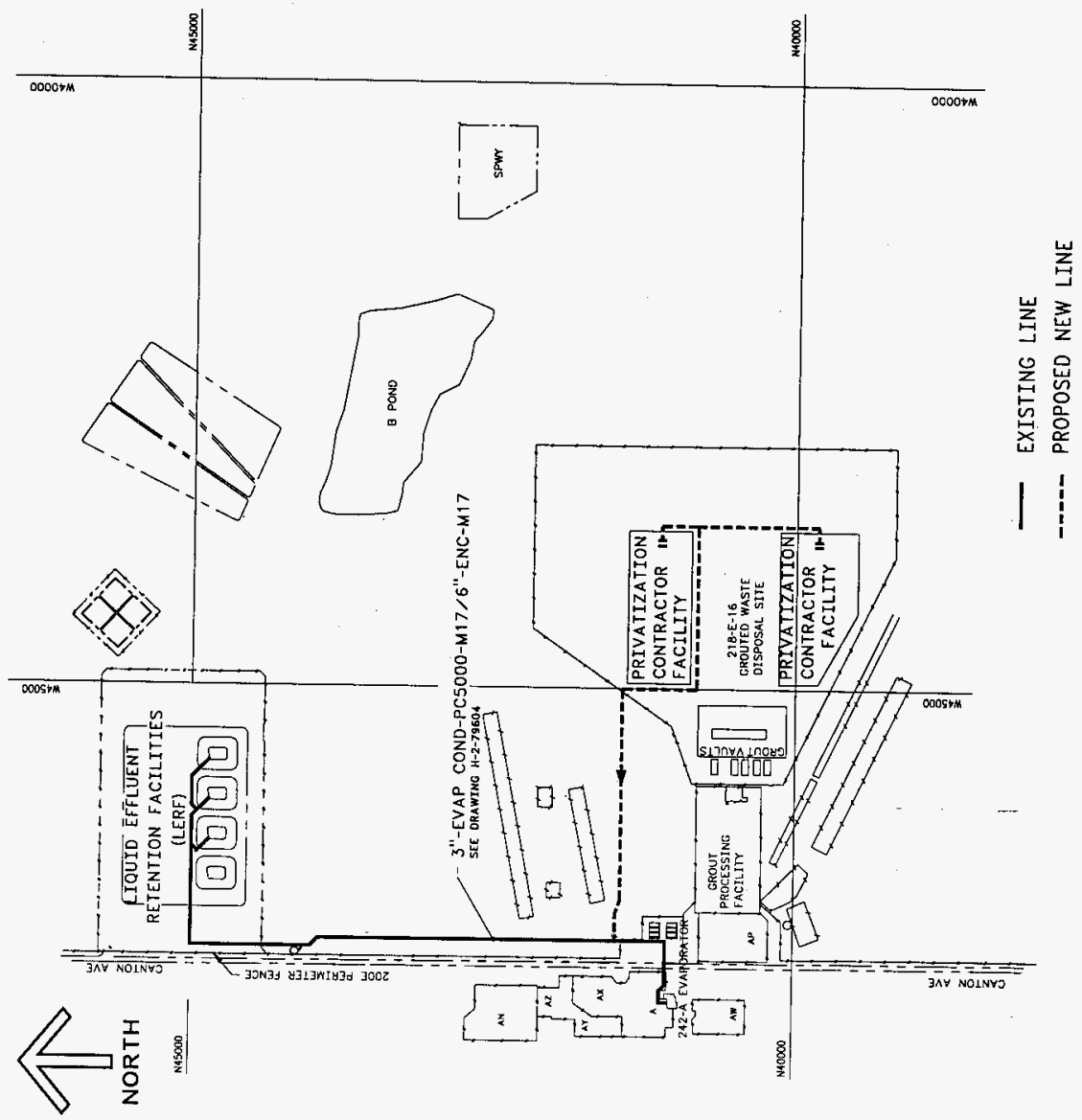

Figure 3.2-2 Radioactive,Dangerous Liquid Effluent Transfer System 


\subsubsection{PHYSICAL CHARACTERISTICS}

The transfer system components and piping shall be constructed of materials that are compatible with the effluent to be placed in the primary system and must have sufficient strength and thickness to prevent failure owing to physical contact with the effluent to which it is exposed, climatic conditions, and the stress of daily operation (including stresses from nearby vehicular traffic) to meet the reliability requirements outlined in Section 3.2.5.1.

\subsubsection{Protective Coatings}

This paragraph is not applicable to this specification.

\subsubsection{SYSTEM QUALITY FACTORS}

3.2.5.1 Reliability The degree of redundancy, reliability, and availability shall correspond to a systematically determined safety classification for all systems, structures, and components. An approved reliability Availability, and Maintainability (RAM) analysis shall be performed for the designed system.

3.2.5.1.1 Design Life The effluent transfer system shail be designed for a service life of 15 years.

3.2.5.1.2 Mean Time Between Failure (MTBF) Requirements cannot be identified at this time.

3.2.5.2 Maintainability. The design of equipment shall incorporate the objective of efficient maintainability. The surveillance, testing, and maintenance of a system and its restoration to operational effectiveness shall be achieved at minimum cost with a minimum level of support services. Maintenance, inspection, and testing capabilities shall be incorporated where required in the design in accordance with DOE Order 6430.1A, section 1300-3.5.

3.2.5.2.1 Accessibility. The system design shall consider the maintainability factors peculiar to the specific equipment to be used in the facility. Facility design shall provide for routine maintenance, repair, or replacement of equipment subject to failure. Ancillary equipment shall be located in areas least likely to be contaminated.

3.2.5.2.2 Testing. The design shall include provisions for periodic testing of piping, monitoring, surveillance, and alarm systems. In addition, the design shall provide the capability to test periodically, under simulated emergency conditions, safety class items that are required to function under emergency conditions. Safety class systems shall be in place testable in terms of 
pressure, filtration or removal efficiency, alarm capability, leak resistance, and the like. Safety class items shall be designed to be testable on a regular schedule.

3.2.5.2.3 Shielding. Where permanent shielding is impractical and operational or maintenance access is required, the distance between radioactive components shall be designed to permit installation of temporary shielding around items that contribute substantially to the dose rate.

3.2.5.2.4 Future Use. Facilities or modifications to facilities shall be designed such that, at the end of the facility's design life, exposures during surplus facility maintenance, surveillance, and decontamination or decommissioning activities shall be As Low As Reasonably Achievable (ALARA) (WHC-IP1043).

3.2.5.2.5 Mean Time to Repair (MTTR). Requirements cannot be identified at this time.

3.2.5.3 Availability. The effluent transfer system shall be available to perform transfers throughout its design life.

\subsubsection{Additional Quality Factors}

This paragraph is not applicable to this specification.

\subsubsection{ENVIRONMENTAL CONDITIONS.}

The Effluent Transfer System shall be designed to withstand the environmental conditions specified below while performing to the requirements specified in 3.2.1.

3.2.6.1 External - Weather Related. The effluent transfer system shall be designed to withstand the natural environments of the Hanford Site listed below. Thermal effects of the soil shall also be considered for the buried portions of the system.

Temperatures:

Maximum temperature: $\quad 48.9^{\circ} \mathrm{C}\left(120^{\circ} \mathrm{F}\right)$

Minimum Temperature: $\quad-35.5^{\circ} \mathrm{C}\left(-32^{\circ} \mathrm{F}\right)$

Rate of increase:

$28.9^{\circ} \mathrm{C}\left(52^{\circ} \mathrm{F}\right)$ per 24 hours, maximum

$\mathrm{pH}$ Range

$2.0-12.5$

Relative Humidity:

The system shall be designed to operate within a relative humidity range of 0 to $100 \%$

Precipitation: 
The system shall be designed to withstand a 25 year, 24 hour mean precipitation of $4 \mathrm{~cm}(1.56 \mathrm{in})$.

Blowing Dust and Smoke:

The system shall be designed to withstand periods of blowing dust and smoke with the following characteristics:

Visibility:

$9.65 \mathrm{~km}$ (6 miles) or less with sky completely obscured

Frequency: $\quad 10$ times per year, maximum

Duration: 24 hrs. per occurrence

3.2.6.2 External - Natural Induced Forces. All Effluent Transfer System safety class components shall comply with the design loads for nonreactor structures specified in "Hanford A/E Standards, Architectural/Civil, GC-LOAD-01, Design Loads for Facilities".

3.2.6.3 Internal - Radionuclide. The Effluent Transfer System elements shall be capable of withstanding the worst case liquid waste radionuclide concentrations acceptable for treatment at the ETF.

3.2.6.4 Internal - Effluent Chemical Characteristics. The Effluent Transfer System elements shall be capable of withstanding the liquid waste chemical composition ranges acceptable for treatment at the TEDF or ETF.

3.2.6.5 Internal - Pressure. Effluent Transfer System elements shall withstand the maximum pressure developed at the PC facility and required to move the effluent from the PC facility to the disposal facility.

\subsubsection{TRANSPORTABILITY.}

The effluent transfer system elements shall be designed to be handled, packaged, marked and transported in accordance with DOE Order 1540.1, "Materials Transportation and Traffic Management" to assure materials reach destination in good order.

\subsubsection{FLEXIBILITY AND EXPANSION.}

The system shall incorporate a design that addresses anticipated future needs. Changeable, movable and demountable material shall be considered where functional requirements are likely to change. Design solutions shall demonstrate methods for modification and expansion including modularity, additional capacities (unless otherwise restricted in other sections of these criteria), and other techniques when justified on a Life Cycle Cost (LCC) basis. 


\subsubsection{PORTABILITY.}

This paragraph is not applicable to this specification.

\subsection{DESIGN AND CONSTRUCTION}

The system shall be designed and constructed in accordance with DOE Order 6430.1A, General Design Criteria. The criteria in Sections 99.0, "Non-Nuclear Facilities - General", Section 99.17, "Radioactive Liquid Waste Facilities" and Section 1300 "Special Facilities" are applicable.

\subsubsection{MATERIALS.}

3.3.1.1 Toxic Products and Formulations. The effluent transfer system shall be designed without components or hardware which uses asbestos, Polychlorinated Biphenyls (PCBs), or ozone depleting chemicals.

3.3.1.2 Secondary Containment. All waste bearing elements of the radioactive, dangerous effluent transfer system shall be doubly contained.

3.3.1.2.1 Materials. The secondary containment system shall be constructed of materials that are compatible with the effluent to be transferred.

\subsubsection{Underground Pipe.}

3.3.1.3.1 Backfill Material. The effluent transfer system components that are placed underground and backfilled shall be provided with a backfill material that is a noncorrosive, porous, homogeneous substance and that is installed so that the backfill is placed completely around the system and compacted to ensure that the buried system is fully and uniformly supported.

3.3.1.4 Decontamination and Decommissioning. The effluent transfer system and its components shall be designed to facilitate decontamination for maintenance and operations, and to simplify decontamination and decommissioning and/or increase the potential for reuse.

3.3.1.4.1 Hazardous Materials Handling. The effluent transfer system elements shall be designed to be handled, packaged, marked and transported in accordance with WHC-CM-2-14 "Hazardous Materials Packaging and Shipping" so that transfer system elements can be appropriately transported following usage (e.g., to maintenance depots, to deactivation facilities at the end of their design life, etc.l.

3.3.1.5 Smooth Surfaces. All surfaces that are potentially susceptible to exposure to contamination shall be designed to have a smooth, non-porous, surface finish 
which is free of cracks, crevices, and sharp corners.

3.3.1.6 Corrosion Protection. The Effluent Transfer System shall implement corrosion protection to achieve the design life specified in 3.2.5.1.1. This shall be accomplished through the use of corrosion resistant materials for Effluent Transfer System elements in contact with the corrosive environmental conditions specified in section 3.2.6. In addition, dissimilar metals and soil shall be considered and corrosion protection system implemented where needed.

\subsubsection{ELECTROMAGNETIC RADIATION.}

This paragraph is not applicable to this specification.

\subsubsection{NAMEPLATES AND PRODUCT MARKINGS.}

Specific guidelines for addressing labeling shall be followed and are contained in NUREG 0700, Section 6.6, MIL-STD-1472D, Section 5.5 and the DOE Order for Conduct of Operations, DOE 5480.19, Chapter 18, Equipment Piping and Labeling.

3.3.3.1 Equipment Labeling. Equipment and any parts of that equipment to be used by personnel shall be identified with appropriate labels. The label shall indicate clearly and concisely the function and purpose of the item being labeled.

3.3.3.2 Durability. Permanent labels shall be attached to the specific component or equipment in such a manner that environmental conditions or usage by personnel will not remove or destroy the label.

3.3.3.3 Legibility. Labeling shall be legible and conform to human visual capabilities and limitations in regard to physical characteristics such as letter and symbol size, contrast, font, simplicity, spacing and stroke width.

\subsubsection{WORKMANSHIP}

The effluent transfer system elements shall conform to the workmanship standards specified in WHC-IP-1140, "Workmanship Standards".

\subsubsection{INTERCHANGEABILITY.}

This paragraph is not applicable to this specification.

\subsubsection{SAFETY.}

It is the policy of the Project Hanford Management Contractor to assure that alf 
activities are strictly controlled, from design, to operation and maintenance, all components, systems, and processes must meet safety and environmental requirements. Requirements and standards outlined in DOE 5480.4, Environmental Protection, Safety and Health Protection, applicable to system design shall be incorporated for safety.

\subsubsection{Personnel Safety.}

3.3.6.1.1 Radiological Safety. The design shall minimize exposures of personnel and the general public to hazardous materials by emphasizing ALARA concern during all design, construction, and operational phases.

3.3.6.1.1.1 General Public Dose Limit. The system shall be designed such that exposure of members of the public to radiation sources as a consequence of all routine DOE activities, including transfer activities, shall not cause, in a year, an effective dose equivalent greater than $1 \mathrm{mSv}(100 \mathrm{mrem})$.

3.3.6.1.1.2 Occupational Worker. The dose rates for the occupational worker shall not exceed the dose rate specified in Section 3.3.6.1.1.3.a.

3.3.6.1.1.3 Radiological Design. The effluent transfer system design shall follow the general design criteria contained in $10 \mathrm{CFR} 835$, DOE Order 6430.1 A and WHC-SD-GN-DGS-30011 and shall incorporate the following into the design:

a. Individual worker dose shall be ALARA and should be less than $5 \mathrm{mSv}$ (500 mrem) per year

b. Discharges of radioactive liquid to the environment are covered by the provisions of DOE 5400.5 and should not degrade the groundwater.

c. Control of contamination should be achieved by containment of radioactive material

d. Efficiency of maintenance, decontamination, operations, and decommissioning shall be maximized.

e. Components should be selected to minimize the buildup of radioactivity.

f. Support facilities shall be provided for donning and removal of protective clothing and for personnel monitoring, when required.

g. Neutron quality factor of 20 for conditions of unknown spectra (or doubling of the neutron quality factor associated with known neutron energies) should be used for design purposes. Design analyses based on these neutron quality factors are intended to be used to estimate the additional construction cost that would result if the neutron quality factor was increased. The results of these analyses should be used to ascertain the economic feasibility for incorporating such modifications in the final design.

3.3.6.1.1.4 Best Available Technology. For facility design, Radiation Protection 
Equipment and hardware that impacts personnel or public radiation exposure shall meet Best Available Technology (BAT) criteria. BAT is the use of the most current proven state-of-the-art instrumentation, dosimetry and other hardware to enhance and improve the radiation protection of personnel and the public with only a small weighing factor given to the economic impact.

3.3.6.1.2 Lock \& Tag. The effluent transfer system shall be designed to accept lockout devices on components and systems to protect against the unexpected release of all sources of hazardous energy or materials. Examples include, but are not limited to: electrical, mechanical, hydraulic, pneumatic, chemical, radiation, and thermal energies, as well as various forms of potential (stored) energy, such as in springs, compressed gases, or suspended objects.

3.3.6.1.3 Fire Protection. Fire protection provisions for the liquid effluent transfer system and its components shall comply with DOE 6430.1A, Section 1530 and DOE 5480.7A.

3.3.6.2 System Safety.

3.3.6.2.1 Interlocks. The transfer system shall be designed to secure and isolate a transfer of radioactive waste in the event of a system failure (i.e., primary containment failure).

\subsubsection{HUMAN ENGINEERING.}

Human Factors criteria documented in DOE 6430.1A, Section 1300-12 shall apply to the construction and operation of the effluent transfer system.

3.3.7.1 Human Dimension. Equipment that is to be used by personnel shall be designed or selected to accommodate their body dimensions. This equipment includes control panels, work tables and counters, enclosures, seating, storage, special clothing, and any other equipment designed for an operator. The design of equipment for personnel shall accommodate a wide variety of body dimensions. Generally, it is recommended that equipment dimensions accommodate the fifth to ninety-fifth percentile of the user population. For recommended data representing these percentiles, see NUREG 0700, Section 6.1, and MIL-STD-1472D, Section 5.6.

\subsubsection{NUCLEAR CONTROL}

This paragraph is not applicable to this specification.

\subsubsection{SECURITY.}


Existing safeguards and security measures will not be impacted by the Effluent Transfer System or its operation. No new measures beyond current practices will be required for the effluent transfer system.

\subsubsection{GOVERNMENT FURNISHED PROPERTY USAGE.}

This paragraph is not applicable to this specification.

\subsubsection{COMPUTER RESOURCE RESERVE CAPACITY.}

This paragraph is not applicable to this specification.

\subsubsection{PIPING AND ANCILLARY EQUIPMENT DESIGN AND CONSTRUCTION.}

3.3.12.1 Placement. The secondary containment system shall be sloped to allow for drainage, accumulation, and removal of liquids resulting from leaks or spills.

3.3.12.2 Structural Support. The structural support design for the secondary containment systems must be at a minimum, placed on a foundation or base capable of providing support to the secondary containment system, resistance to pressure gradients above and below the system, and capable of preventing failure due to settlement, compression, or uplift.

3.3.12.3 Containment. Ancillary equipment shall be provided with secondary containment (e.g., trench, jacketing, double-walled piping).

3.3.12.4 Physical Protection. The ancillary equipment shall be supported and protected against physical damage and excessive stress due to settlement, vibration, expansion, or contraction.

\subsection{DOCUMENTATION}

Records, documents, and document control pertinent to design functions shall be in accordance with WHC-CM-3-5. Drafting Standards for drawings shall be in accordance with ICF Kaiser Company's A/E General Standards, GG-DWG-01, Revision 0 . No requirements in accordance with any applicable state or federal regulations have not been identified at this time.

\subsection{LOGISTICS}

\subsubsection{MAINTENANCE AND OPERATION}

Remote, limited, or contact maintenance and operation will be in accordance with the following threshold values. The requirements of hazardous materials and associated maintenance and operation considerations, if applicable, have not been 
identified at this time.

3.5.1.1 Fully Remote Maintenance and Operation. Each system or portion of a system having radiation levels greater than $50 \mathrm{mrem} / \mathrm{hr}$ contact exposure will be designed to be remotely maintained and operated or designed to require no maintenance and be remotely operated.

3.5.1.2 Limited Contact Maintenance and Operation. Each system or portion of a system having radiation levels greater than $0.25 \mathrm{mrem} / \mathrm{hr}$ to less than or equal to $50 \mathrm{mrem} / \mathrm{hr}$ will be designed for limited contact maintenance and operation. Designs shall consider remote removal of radiation sources and decontamination prior to personnel entry.

3.5.1.3 Full Contact Maintenance and Operation. Each system or portion of a system having radiation levels less than or equal to $0.25 \mathrm{mrem} / \mathrm{hr}$ will be designed for full contact maintenance and operation.

\subsubsection{WASTE HANDLING, STORAGE, AND DISPOSAL}

Solid waste handling, storage and disposal shall be performed in accordance with WHC-SD-GN-DGS-30011, Section 10.1 through 10.3 and WHC-CM-7-5, Section 7.0.

\subsubsection{TRANSPORTATION OF HAZARDOUS MATERIALS.}

This paragraph is not applicable to this specification.

\subsubsection{SUPPLY/SUPPORT.}

The system design shall, to the greatest extent practicable, use readily available parts and components.

\subsection{PERSONNEL AND TRAINING}

\subsubsection{PERSONNEL}

This paragraph is not applicable to this specification.

\subsubsection{TRAINING}

This paragraph is not applicable to this specification.

\subsection{CHARACTERISTICS OF SUBORDINATE ELEMENTS}

Requirements cannot be identified at this time. 


\subsection{PRECEDENCE}

This DRD documents the appropriate functions, requirements, interfaces, and architectures to ensure that the identified mission of the liquid effluent transfer systems is: (a) adequately integrated into the overall TWRS mission and other projects; and (b) designed to the proper system level requirements. For the precedence of requirements contained herein, see the TWRS Systems Engineering requirements database (WHC-SD-WM-FRD-020, RDD-100) for their hierarchial relationships. Those requirements which are the closest to the "imposed" requirements in the hierarchy (e.g., CFRs, DOE Orders, etc.) shall carry precedence over those requirements several layers removed from the imposed requirement.

\subsection{QUALIFICATION}

See section 4.0 .

\subsection{STANDARD SAMPLE}

This paragraph is not applicable to this specification.

\subsection{PREPRODUCTION SAMPLE, PERIODIC PRODUCTION SAMPLE, PILOT OR PILOT LOT}

This paragraph is not applicable to this specification.

\subsection{QUALITY ASSURANCE PROVISIONS}

\subsection{RESPONSIBILITY FOR INSPECTION}

The design contractor shall be responsible for the performance of all inspections for each system developed in accordance with this DRD. Inspections shall be conducted at the contractor facilities or the facilities of his choice with the approval of the procuring authority. The procuring authority reserves the right to witness or perform the specified inspections.

\subsection{SPECIAL TESTS AND EXAMINATIONS}

Any special tests and examinations required for sampling, lot formation, qualification evaluation, and any other tests or examinations as necessary shall be define within the design documents for the project.

\subsection{REQUIREMENTS CROSS REFERENCE}


Qualification shall be performed on system hardware representative of the approved production design. Qualification of the system to assure compliance with the requirements of Section 3 shall be by examination, demonstration, test, and analysis, as defined below and shall be satisfied at the level of assembly specified in Table 4.3-1. Test program data may be used to assure compliance with requirements. Definitions of examination, demonstration, test and analysis are as follows:

a. Examination. Examination is an element of inspection consisting of investigation, without the use of special laboratory appliances or procedures to determine compliance with requirements.

b. Demonstration. Demonstration is an element of inspection that is limited to readily observable functional operation to determine compliance with requirements. This element of inspection does not require the use of special equipment or sophisticated instrumentation.

c. Test. Test is an element of inspection that employs technical means including (but not limited to) the evaluation of functional characteristics by use of special equipment or instrumentation, simulation techniques, and the application of established principles and procedures to determine compliance with requirements. The analysis of data derived from test is an integral part of this inspection.

d. Analysis. Analysis is an element of inspection, taking the form of the processing of accumulated results and conclusions, intended to provide proof that verification of a requirement(s) has been accomplished. The analytical results may be comprised of a compilation of interpretation of existing information or derived from lower level examinations, tests, demonstrations, or analysis.

The environmental capability of equipment shall be demonstrated by appropriate testing, analysis, and operating experience, or other methods that can be supported by auditable documentation, or a combination of these methods.

Unless otherwise specified tests shall be made at standard ambient conditions. 
Table 4.3-1 Requirements Cross Reference

\begin{tabular}{|c|c|c|c|c|c|c|c|}
\hline \multirow{2}{*}{$\begin{array}{l}\text { SECTION } 3 \\
\text { PARAGRAPH } \\
\text { NUMBER }\end{array}$} & \multirow[t]{2}{*}{ TITLE } & \multirow{2}{*}{$\begin{array}{l}\text { LEVEL } \\
\text { OF ASSEMBLY }\end{array}$} & \multicolumn{5}{|c|}{ INSPECT ELEMENT } \\
\hline & & & EXAM & DEMO & TEST & ANA & N/A \\
\hline 3.2 & Characteristics & & & & & & $x$ \\
\hline 3.2 .1 & Performance Characteristics & & & & & & $x$ \\
\hline 3.2 .1 .1 & $\begin{array}{l}\text { Non-Radioactive, Non-Dangerous Effluent Discharge Flow } \\
\text { Rate }\end{array}$ & $\mathrm{S}$ & & & $\mathrm{X}$ & & \\
\hline 3.2 .1 .2 & Radioactive, Dangerous Effluent Discharge Flow Rate & $\mathrm{S}$ & & & $x$ & & \\
\hline 3.2 .1 .3 & Minimum Liquid Velocity & $\mathrm{S}$ & & & $\mathrm{X}$ & & \\
\hline 3.2 .1 .4 & Motive Force & $\mathrm{S}$ & & & $x$ & & \\
\hline 3.2 .1 .5 & Monitoring Effluent Stream Parameters & S & & & $x$ & & \\
\hline 3.2 .1 .6 & $\begin{array}{l}\text { Radioactive, Dangerous Effluent Waste Acceptability } \\
\text { Criteria }\end{array}$ & & & & & & $x$ \\
\hline 3.2 .1 .7 & $\begin{array}{l}\text { Non-Radioactive, Non-Dangerous Effluent Acceptance } \\
\text { Criteria }\end{array}$ & & & & & & $x$ \\
\hline 3.2 .2 & System Relationships & & & & & & $x$ \\
\hline 3.2 .3 & External Interface Requirements & & & & & & $\mathrm{X}$ \\
\hline 3.2.3.1 & Physical Descriptions & & & & & & $\mathrm{X}$ \\
\hline 3.2 .3 .2 & Non-Radioactive, Non-Dangerous Liquid Effluent & & & & & & $x$ \\
\hline 3.2 .3 .3 & Radioactive, Dangerous Liquid Effluent & & & & & & $\mathrm{X}$ \\
\hline
\end{tabular}


WHC-SD-WM-DRD-014

Revision 0

\begin{tabular}{|c|c|c|c|c|c|c|c|}
\hline \multirow{2}{*}{$\begin{array}{l}\text { SECTION } 3 \\
\text { PARAGRAPH } \\
\text { NUMBER }\end{array}$} & \multirow[t]{2}{*}{ TITLE } & \multirow{2}{*}{$\begin{array}{c}\text { LEVEL } \\
\text { OF ASSEMBLY }\end{array}$} & \multicolumn{5}{|c|}{ INSPECT ELEMENT } \\
\hline & & & EXAM & DEMO & TEST & ANA & $\mathrm{N} / \mathrm{A}$ \\
\hline 3.2 .4 & Physical Characteristics & & & & & & $\mathrm{x}$ \\
\hline 3.2.4.1 & Protective Coatings & & & & & & $x$ \\
\hline 3.2 .5 & System Quality Factors & & & & & & $x$ \\
\hline 3.2 .5 .1 & Reliability & & & & & & $\mathrm{x}$ \\
\hline 3.2 .5 .1 .1 & Design Life & C & $x$ & & & & \\
\hline 3.2 .5 .1 .2 & Mean Time Between Failure (MTBF) & C & $\mathrm{x}$ & & & & \\
\hline 3.2 .5 .2 & Maintainability & $\mathrm{S}$ & $\mathrm{x}$ & & & & \\
\hline 3.2 .5 .2 .1 & Accessibility & $\mathbf{S}$ & $x$ & & & & \\
\hline 3.2 .5 .2 .2 & Testing & C & $x$ & & & & \\
\hline 3.2.5.2.3 & Shielding & C & $x$ & & & $x$ & \\
\hline 3.2 .5 .2 .4 & Future Use & $\mathbf{S}$ & $\mathrm{x}$ & & & & \\
\hline 3.2 .5 .2 .5 & Mean Time to Repair (MTTR) & & & & & $x$ & \\
\hline 3.2 .5 .3 & Availability & & & & & $x$ & \\
\hline 3.2 .5 .4 & Additional Quality Factors & & & & & & $x$ \\
\hline 3.2 .6 & Environmental Conditions & & & & & & $x$ \\
\hline 3.2 .6 .1 & External - Weather Related & $\mathrm{S}$ & & & & $x$ & \\
\hline 3.2 .6 .2 & External - Nature Induced Forces & $S$ & & & & $x$ & \\
\hline
\end{tabular}




\begin{tabular}{|c|c|c|c|c|c|c|c|}
\hline \multirow{2}{*}{$\begin{array}{c}\text { SECTION } 3 \\
\text { PARAGRAPH } \\
\text { NUMBER }\end{array}$} & \multirow[t]{2}{*}{ TITLE } & \multirow{2}{*}{$\begin{array}{c}\text { LEVEL } \\
\text { OF ASSEMBLY }\end{array}$} & \multicolumn{5}{|c|}{ INSPECT ELEMENT } \\
\hline & & & EXAM & DEMO & TEST & ANA & $\mathrm{N} / \mathrm{A}$ \\
\hline 3.2 .6 .3 & Internal - Radionuclide & $\mathrm{S}$ & & & & $\mathrm{x}$ & \\
\hline 3.2.6.4 & Internal - Effluent Chemical Characteristcs & $\mathrm{S}$ & & & & $\mathrm{x}$ & \\
\hline 3.2 .6 .5 & Internal - Pressure & $\mathrm{S}$ & & & $x$ & & \\
\hline 3.2 .7 & Transportability & & & & & & $x$ \\
\hline 3.2 .8 & Flexibility and Expansion & $\mathbf{S}$ & & & & $x$ & \\
\hline 3.2 .9 & Portability & & & & & & $\mathrm{x}$ \\
\hline 3.3 & Design and Construction & & & & & & $x$ \\
\hline 3.3 .1 & Materials & & & & & & $x$ \\
\hline 3.3.1.1 & Toxic Products and Formulations & $\mathrm{C}$ & $x$ & & & & \\
\hline 3.3.1.2 & Secondary Containment & $\mathrm{S}$ & & & & $\mathrm{X}$ & \\
\hline 3.3.1.2.1 & Materials & C & $x$ & & & & \\
\hline 3.3.1.3 & Underground Pipe & $\mathrm{C}$ & $x$ & & & & \\
\hline 3.3.1.3.1 & Backfill Material & $\mathrm{C}$ & $\mathrm{x}$ & & & & \\
\hline 3.3 .1 .4 & Decontamination and Decommissioning & $\mathrm{C}$ & $x$ & & & & \\
\hline 3.3.1.4.1 & Hahardous Materials Handling & $\mathrm{C}$ & $x$ & & & & \\
\hline 3.3 .1 .5 & Smooth Surfaces & $\mathrm{C}$ & $\mathrm{x}$ & & & & \\
\hline 3.3.1.6 & Corrosion Protection & C & $\mathrm{x}$ & & & $x$ & \\
\hline
\end{tabular}


WHC-SD-WM-DRD-014

Revision 0

\begin{tabular}{|c|c|c|c|c|c|c|c|}
\hline \multirow{2}{*}{$\begin{array}{l}\text { SECTION } 3 \\
\text { PARAGRAPH } \\
\text { NUMBER }\end{array}$} & \multirow[t]{2}{*}{ TITLE } & \multirow{2}{*}{$\begin{array}{l}\text { LEVEL } \\
\text { OF ASSEMBLY }\end{array}$} & \multicolumn{5}{|c|}{ INSPECT ELEMENT } \\
\hline & & & EXAM & DEMO & TEST & ANA & N/A \\
\hline 3.3 .2 & Electromagnetic Radiation & & & & & & $x$ \\
\hline 3.3 .3 & Nameplates and Product Markings & $\mathrm{C}$ & $\mathrm{x}$ & & & & \\
\hline 3.3.3.1 & Equipment Labelling & C & $x$ & & & & \\
\hline 3.3.3.2 & Durability & C & & & & $x$ & \\
\hline 3.3.3.3 & Legibility & $\mathrm{C}$ & $\mathrm{x}$ & & & & \\
\hline 3.3 .4 & Workmanship & C & $\mathrm{x}$ & & & & \\
\hline 3.3 .5 & Intrchangeability & C & $x$ & & & & \\
\hline 3.3 .6 & Safety & $\mathrm{C}$ & & & & $x$ & \\
\hline 3.3.6.1 & Personnel Safety & & & & & & $x$ \\
\hline 3.3.6.1.1 & Radiological Safety & $s$ & & & & $x$ & \\
\hline 3.3.6.1.1.1 & General Public Dose Limit & $\mathrm{s}$ & & & & $x$ & \\
\hline 3.3.6.1.1.2 & Occupational Worker & $\mathrm{s}$ & & & & $x$ & \\
\hline 3.3.6.1.1.3 & Radiological Design & $\mathrm{C} / \mathrm{s}$ & & & & $x$ & \\
\hline 3.3.6.1.1.4 & Best Available Technology & C & $x$ & & & & \\
\hline 3.3.6.1.2 & Lock \& Tag & $\mathrm{C}$ & $x$ & & & & \\
\hline 3.3.6.1.3 & Fire Protection & $\mathrm{C}$ & & & & $x$ & \\
\hline 3.3 .6 .2 & System Safety & & & & & & $x$ \\
\hline
\end{tabular}


WHC-SD-WM-DRD-014

Revision 0

\begin{tabular}{|c|c|c|c|c|c|c|c|}
\hline \multirow{2}{*}{$\begin{array}{l}\text { SECTION } 3 \\
\text { PARAGRAPH } \\
\text { NUMBER }\end{array}$} & \multirow[t]{2}{*}{ TITLE } & \multirow{2}{*}{$\begin{array}{c}\text { LEVEL } \\
\text { OF ASSEMBLY }\end{array}$} & \multicolumn{5}{|c|}{ INSPECT ELEMENT } \\
\hline & & & EXAM & DEMO & TEST & ANA & N/A \\
\hline 3.3 .6 .2 .1 & Interlocks & $\mathrm{C} / \mathrm{S}$ & & & & $x$ & \\
\hline 3.3 .7 & Human Engineering & $\mathrm{S}$ & $x$ & & & & \\
\hline 3.3.7.1 & Human Dimension & C & & $x$ & & & \\
\hline 3.3 .8 & Nuclear Control & & & & & & $x$ \\
\hline 3.3 .9 & Security & S & & $x$ & & & \\
\hline 3.3 .10 & Government Furnished Property Usage & & & & & & $x$ \\
\hline 3.3 .11 & Computer Resource Reserve Capacity & & & & & & $x$ \\
\hline 3.3 .12 & Piping and Ancillary Equipment Design and Construction & $\mathbf{S}$ & & & & $x$ & \\
\hline 3.3 .12 .1 & Placement & $\mathrm{C}$ & $x$ & & & & \\
\hline 3.3 .12 .2 & Structural Support & C & $x$ & & & & \\
\hline 3.3 .12 .3 & Containment & C & & & $x$ & & \\
\hline 3.3 .12 .4 & Physical Protection & $\mathrm{C}$ & $\mathrm{x}$ & & & & \\
\hline 3.4 & Documentation & & & & & & $\mathrm{x}$ \\
\hline 3.5 & Logistics & & & & & & $x$ \\
\hline 3.5 .1 & Maintenance and Operation & $\mathrm{C}$ & $\mathrm{x}$ & & & & \\
\hline 3.5 .1 .1 & Fully Remote Maintenance and Operation & $S$ & $x$ & & & & \\
\hline $3.5,1.2$ & Limited Contact Maintenance and Operation & $\mathrm{S}$ & $x$ & & & & \\
\hline
\end{tabular}




\begin{tabular}{|c|c|c|c|c|c|c|c|}
\hline \multirow{2}{*}{$\begin{array}{l}\text { SECTION } 3 \\
\text { PARAGRAPH } \\
\text { NUMBER }\end{array}$} & \multirow[t]{2}{*}{ TITLE } & \multirow{2}{*}{$\begin{array}{l}\text { LEVEL } \\
\text { OF ASSEMBLY }\end{array}$} & \multicolumn{5}{|c|}{ INSPECT ELEMENT } \\
\hline & & & EXAM & DEMO & TEST & ANA & N/A \\
\hline 3.5 .1 .3 & Full Contact Maintenance and Operation & $\mathrm{C}$ & $x$ & & & & \\
\hline 3.5 .2 & Waste Handling, Storage, and Disposal & $\mathrm{C}$ & $x$ & & & & \\
\hline 3.5 .3 & Transportation of Hazardous Materials & & & & & & $x$ \\
\hline 3.5 .4 & Supply/Support & C & $x$ & & & & \\
\hline 3.6 & Personnel and Training & & & & & & $\mathrm{x}$ \\
\hline 3.6 .1 & Personnel & & & & & & $\mathrm{X}$ \\
\hline 3.6 .2 & Training & & & & & & $x$ \\
\hline 3.7 & Characteristics of Subordinate Elements & & & & & & $\mathrm{x}$ \\
\hline 3.8 & Precedence & & & & & & $\mathrm{x}$ \\
\hline 3.9 & Qualification & & & & & & $x$ \\
\hline 3.10 & Standard Sample & & & & & & $x$ \\
\hline 3.11 & $\begin{array}{l}\text { Preproduction Sample, Periodic Production sample, Pilot or } \\
\text { Pilot Lot }\end{array}$ & & & & & & $x$ \\
\hline
\end{tabular}

$\mathrm{S}=$ System, $\mathrm{I}=$ Intermediate, and $\mathrm{C}=$ Component 


\subsection{PREPARATION FOR DELIVERY}

This paragraph is not applicable to this specification.

\subsection{NOTES}

\subsection{INTENDED USE}

The intended use of the liquid effluent transfer system is to provide a means by which effluents can by transferred from the PC facilities and the 200 East Area effluent disposal facilities as defined in Section 3.0 of this document.

\subsubsection{Missions}

The mission of the liquid effluent transfer system is described in section 3.1 with the performance characteristics outlined in section 3.2.

\subsubsection{Hazards}

Hazards associated with the liquid effluent transfer system and its design will be documented by the Safety Analysis Report for the system as defined by DOE 5480.23, Nuclear Safety Analysis Reports.

\subsection{DEFINITIONS}

\subsubsection{RADIOACTIVE. DANGEROUS LIQUID EFFLUENT}

Dilute process waste liquid effluents which require treatment and meet interface acceptance criteria for discharge directly, or with minimal pretreatment, to the Liquid Effluent Retention Facility (LERF) and/or to the Effluent treatment Facility (ETF) for subsequent treatment in accordance with State Waste discharge Permit No. ST-4500.

\subsubsection{NON-RADIOACTIVE, NON-DANGEROUS LIQUID EFFLUENT}

Uncontaminated waste water which meets interface acceptance criteria for discharge directly to the 200 Area treated Effluent Disposal Facility (TEDF) as specified in State Waste discharge Permit No. ST-4502.

\subsection{ABBREVIATIONS AND ACRONYMS}

The acronyms and abbreviations listed below are used in this specification. 
$\mathrm{ACP}$

ALARA

BAT

DOE

DRD

DST

ETF

gpm

HLW

IP

LCC

LERF

LLW

Mgal

MTBF

MTTR

PC

PCB

PHMC

RAM

RCRA

TEDF

TWRS

WAC

WHC
Asphalt Concrete Pavement

As Low As Reasonable Achievable

Best Available Technology

Department of Energy

Design Requirements Document

Double Shell Tank

Effluent Treatment Facility

gallon per minute

High Level Waste

Infrastructure Project

Life Cycle Cost

Liquid Effluent Retention Facility

Low Level Waste

million gallons

Mean Time Between Failure

Mean Time To Repair

Privatization Contractor

Polychlorinated Byphenyls

Project Hanford Management Contractor

Reliability, Availability, and Maintainability

Resource Conservation and recovery Act

Treated Effluent Disposal Facility

Tank Waste Remediation System

Washington Administrative Code

Westinghouse Hanford Corporation

\subsection{APPENDICES}

The requirement of this section cannot be identified at this time. 


\section{DISTRIBUTION SHEET}

\begin{tabular}{|c|c|c|c|c|c|}
\hline To & \multirow{2}{*}{\multicolumn{3}{|c|}{$\begin{array}{l}\text { From } \\
\text { WHC TWRS Process Design } \\
\text { R. J. Parazin }\end{array}$}} & \multicolumn{2}{|l|}{ Page 1 of 1} \\
\hline Distribution & & & & \multicolumn{2}{|c|}{ Date $09 / 30 / 96$} \\
\hline \multicolumn{4}{|l|}{ Project Title Work Order } & \multicolumn{2}{|c|}{ EDT No. 618855} \\
\hline \multicolumn{4}{|c|}{$\begin{array}{l}\text { TWRS Privatization Phase I Liquid Effluent Transfer Systems } \\
\text { Design Requirements Document }\end{array}$} & ECN No. $\mathrm{N} / 1$ & \\
\hline Name & MSIN & $\begin{array}{l}\text { Text } \\
\text { With All } \\
\text { Attach. }\end{array}$ & Text Only & $\begin{array}{l}\text { Attach./ } \\
\text { Appendix } \\
\text { Only }\end{array}$ & $\begin{array}{c}\text { EDT/ECN } \\
\text { Only }\end{array}$ \\
\hline
\end{tabular}

U.S. Department of Energy

Richland Operations Office

E. M. Bowers

N. R. Brown

T. R. Hoertkorn

DL. A. Otutherford

R. B. Simmons-Green

$\begin{array}{ll}\text { S7-55 } & x \\ K 6-51 & x \\ B 4-55 & x \\ \text { A2-45 } & x \\ \text { S7-53 } & x\end{array}$

ICF Kaiser Hanford Company

D. L. Fort

G3-12

J. T. Koberg

M. D. Rickenbach

G3-12

G3-12

E. F. Yancey

G3-10

A. N. Palit

G3-12

Pacific Northwest National Laboratory

B. A. Reynolds

P7-19 $x$

Westinghouse Hanford Company

R. U. Elwell

P. Felise

J. S. Garfield

K. A. Gasper

M. N. Is 7 am(2)

A. R. Johnson

D. W. Lindsey

S. S. Lowe

P. C. Miller

R. J. Parazin(f)

S7-12 $x$

B4-5.5 $\quad x$

H5-49 $x$

G3-21 $x$

R3-08 $x$

H6-20 $x$

S6-71 $\quad x$

H6-29 $x$

R1-51 $x$

H5-49 $X$

Central Files (original + 1) A3-88 $\mathrm{X}$ 